Evaluating online resources in terms of learning environment and student attitudes in middle-grade mathematics classes

James E. Earle and Barry J. Fraser

Contact author: $\quad$ Barry J. Fraser $₫$

Barry J. Fraser

Curtin University

GPO Box U1987

Perth Australia 6845

Email: B.Fraser@curtin.edu.au 


\title{
Evaluating online resources in terms of learning environment and student attitudes in middle-grade mathematics classes
}

\begin{abstract}
The main objective of this research was to use learning environment and attitude scales in evaluating online resource materials for supporting a traditional mathematics curriculum. The sample consisted of 914 middle-school students in 49 classes. A second research focus was the validation of the chosen learning environment questionnaire, the Technology-Rich Outcomes-Focused Learning Environment Inventory (TROFLEI), with an ethnically-diverse sample of middle-grade mathematics students in Florida. Finally, we complemented quantitative questionnaire data with qualitative interview data that were analysed thematically. In addition to cross-validating the TROFLEI, our study suggested that the online resource provided neither much advantage nor much disadvantage.
\end{abstract}

Keywords Attitudes, Learning environment, Mathematics education, Online resources, Technology-Rich Outcomes-Focused Learning Environment Inventory (TROFLEI), Thematic analysis

\section{Introduction and background}

In many countries around the world, there is a growing emphasis on measuring student achievement by means of high-stakes tests. As a result, expenditure on textbooks, computers and educational software has been increased in an attempt to help students to prepare for these tests. Although these online resources have been supported by multi-million dollar budgets, 
little research has been undertaken to evaluate their effectiveness, especially in terms of students' perceptions of their learning environment and their attitudes.

In Florida, online software programs were designed to help students in grades 3 to 11 to prepare for the Florida Comprehensive Assessment Test (FCAT). As states and districts look to maximising the return on investment in these educational resources, the efficacy of these programs is an important focus for research. Evaluating the effectiveness of an online resource in mathematics was the main aim of this study. Because, designing valid evaluations of mathematics software programs in terms of high-stakes achievement test performance presents many problems, our study made use of robust instruments that assess students' perceptions of their classroom learning environment and their attitudes towards the subject of mathematics.

In this article, we report an investigation into whether an online resource was effective as a curriculum supplement for traditional mathematics instruction in terms of students' perceptions of their classroom learning environment and their attitudes towards the mathematics program material. Additionally, because we assessed the learning environment with a questionnaire (the Technology-Rich Outcomes-Focused Learning Environment Inventory, TROFLEI) that has had limited use in past research, another goal was to crossvalidate this instrument with our sample of middle-school students in Florida.

Prior to describing the methods used in our study and reporting its results, the following subsections briefly review selected literature in areas relevant to our study, namely, (1) outcomes-focused education, (2) the online resource that was evaluated in our study and (3) attitudes to mathematics (because attitudes were constructs included in our evaluation). Then, in the next major section below, the field of learning environments is reviewed, including historical perspectives, the questionnaire chosen for our study (the TROFLEI), and 
past uses of learning environment criteria in evaluating educational programs (the major thrust of our research).

Outcomes-focused education

Outcomes-focused education, according to $\operatorname{Spady}(1994$, p. 1), involves "starting with a clear picture of what is important for students to be able to do, then organizing the curriculum instruction, and assessment to make sure this learning ultimately happens". Many countries throughout the world have used the model of outcomes-focused education for reform under a variety of names, including New Zealand (Bell, Jones and Carr 1995), South Africa (Aldridge, Laugksch and Fraser 2006; Botha 2002), the UK (Faris 1998) and the USA as performance-based education (Evans and King 1994). In the state of Florida, in particular, this approach is known as competency-based curriculum and includes the shift to Common Core in the United States (Fletcher 2010).

As countries around the world work to meet the demands of a 21 st Century global economy (Education Commission of the States 1995; Kerka 1998), much attention is given to the educational model that will best prepare students for the these demands. The natural tendency is to focus on student achievement as an 'outcomes focus', while at the same time providing increasingly individualised educational plans. An effective system which provides an achievement guarantee is very difficult to achieve (Aldridge and Fraser 2008), but it is becoming easier to provide individualised learning plans by using Information Communications Technology (ICT), which can provide the teacher with a method to accommodate diverse learning styles and paces among students and to enhance students' outcomes. However, the outcomes-focused approach to teaching and learning has been the focus of debate and criticism (e.g. McKernan 1993; Waghid 2003). 
Two different approaches to outcomes-focused education are the traditional/transitional approach and the transformational approach (Forlin and Forlin, 2002; Spady 1993). The former approach focuses on content mastery and curriculum-based objectives, whereas the latter approach involves cross-curricular outcomes that are significant beyond schooling (e.g. working cooperatively or problem solving).

Mathematics online support resources

Educational improvements since World War II have focused in large measure on either improving instructional materials for classroom use or providing teachers with training in the use of new instructional methods, but these efforts seldom have led to detectable, sustainable improvements. With the widespread use of computers and the World Wide Web in classrooms, improvements in student achievement have been forecast, but the instructional effectiveness of online programs remains unproven (Ball and Cohen 1999).

One approach to creating a path to success on the statewide achievement tests in Florida involved web-based educational software to provide a widely-available, uniformlywritten test preparation tool for all students within the state. With advancements in the presentation of materials and the availability of web-based design, instructional software can provide learning opportunities for students in the school environment and home environment, with smart 'phones and tablets recently providing these same opportunities virtually anywhere.

In the design of instructional software, a number of key elements have been shown to be important. Learning abstract mathematical content can be a challenge to students, and research has shown that applying mathematics via real-life situations can enhance critical thinking and mathematical reasoning while improving retention and transfer of learning (Schoenfeld 1992; Verzoni 1997). Other key elements to consider in the design characteristics 
are feedback (Khine 1996) and interactivity as a contributor to motivation (Bolliger and Martindale 2004; Hawkes and Dennis 2003). Of great importance in the design and even the choice of an instructional program is the budgetary element because such programs can be expensive to purchase or license and be complicated to maintain and manage (Fahy 2000; Kim and Sharp 2000).

The online resource used in our study was the FCAT Explorer, which was created by Infinity Software of Tallahassee, Florida, a consulting and software development services company founded in 1994. (The Florida Comprehensive Achievement Test, FCAT, was the statewide achievement test which was designed to align with the Mathematics Florida Standards at the time of our study.) The online program was started in 2000 by the Florida State Department of Education (FLDOE) to offer a grade-specific group of practice problems in both reading and mathematics to all Grade 3-10 public school students in the state (over 1.5 million students). The design of the program was based upon cognitive learning theory for instructional design (Dick and Carey 1996) and incorporated learner motivation elements based upon Keller's ARCS model (Keller 1987; Naime-Diefenbach 1991). The ARCS model denotes Attention, Relevance, Confidence and Satisfaction. Other elements taken into consideration in the design of this online program from the ARCS model include the study of human motivation and the analysis of the target audience, with the aim of providing an opportunity for building confidence and satisfaction. In other words, the ARCS model involves what makes students want to learn. Combining multi-step continuous evaluation, motivational approaches and appropriate content for the grade level (based on the criteria established by the state) created the foundation upon which the online resource was built.

Three different levels provide benchmark-specific problems for grades 5, 8 and 10 . The practice items provided at each of these grade levels allow answers to be given in either a multiple-choice format or using a fill-in grid referred to as a gridded response item. The 
mathematics at each grade level is aligned to the appropriate benchmarks, namely, the Sunshine State Standards until 2007 and then the Next Generation Sunshine State Standards until 2014. Also, this program provides Correct Answer Explanation (CAE), that provides students with a simple explanation of the problem and its related concepts when students answer the question correctly. If the student does not answer the question correctly, the program provides a hint and a second chance to apply the hint. A student who is unsuccessful at the second attempt is moved to the next problem but the missed problem is placed on a challenge list. Teachers can access feedback about performance results for their students. Performance data can be displayed by student or by class.

Attitudes to mathematics: Test of Mathematics Related Attitudes (TOMRA)

Attitudes have been considered a central concept in the field of psychology for a long time, with Allport (1935) noting that "this concept is probably the most distinctive and indispensable concept in contemporary American social psychology" (p. 43). An attitude can be defined as "a psychological tendency that is expressed by evaluating a particular entity with some degree of favor or disfavor" (Eagly and Chaiken 1993, p. 1). Attitude can have: a cognitive component, which involves thoughts, beliefs or ideas about an attitude object; an affective component which involves feelings or emotions that the attitude object evokes; and a behavioral component which involves a tendency or disposition to act in certain ways towards the attitude object (McGuire 1969). Specifically, in mathematics education, attitude is an emotional disposition towards mathematics, such as the likes and dislikes of students, the enjoyment that they feel during lessons, and the preferences that they have during mathematics instruction (Aiken 2002).

To measure students' attitudes towards mathematics, our study made use of the Test of Mathematics Related Attitudes (TOMRA), which is based on the Test of Science Related 
Attitudes (TOSRA) (Fraser 1981). Designed to measure secondary students' attitudes towards science, the TOSRA distinguishes between seven separate and distinct science-related attitudes that are built upon Klopfer's (1971) six categories of attitudes. One advantage of the TOSRA is that it provides a profile of attitude scores over the category range and, while the results are difficult to interpret on an absolute scale, they can provide a comparative interpretation (Fraser, 1981).

Kind, Jones and Barmby (2007) drew on the work of Munby $(1983,1997)$, Schibeci and McGaw (1981) and Osborne, Simons and Collins (2003) in identifying numerous important and long-standing problems related to many of the attitude scales developed in the past. Some of these include: the lack of clarity in the description for the constructs to be measured; the combining of conceptually-different constructs to form one unidimensional scale; low reliability of measurement; and failure to address construct validity. TOSRA was selected and modified for use in this study because it overcomes most of these problems. First, the TOSRA clearly defines each of the constructs to be measured by providing distinct subscales based on Klopfer's (1971) classification of students' attitudinal aims. Second, the TOSRA does not combine conceptually-different constructs to form one scale. Third, past studies that have used the TOSRA provide strong evidence of its psychometric quality in terms of scale reliability. Fourth, each scale of TOSRA has demonstrated unidimensionality and independence in past studies through factor analysis. When Munby investigated the adequacy of 56 attitude instruments using criteria similar to those described by Kind, Jones and Barmby (2007), he described TOSRA as "an exceptionally well developed scale" (Munby 1983, p. 314).

Although the TOSRA was designed originally to assess students' attitudes specifically to the subject of science, various researchers have adapted it for other subjects. In particular, several researchers in the USA changed the word 'science' to 'mathematics' to form the Test 
of Mathematics Related Attitudes (TOMRA). Examples of studies that used TOMRA are Ogbuehi and Fraser's (1997) research in California and Spinner and Fraser's (2005) study in Florida. In Singapore, TOSRA was modified to form the Test of Chemistry Related Attitudes (TOCRA) and used it with 1592 final-year chemistry students (Wong, Young and Fraser 1997) and 497 tenth-grade chemistry students (Quek, Wong and Fraser 2005). In Texas, Walker (2006) modified TOSRA to form the Test of Geography Related Attitudes (ToGRA) and validated it with 388 grade 9 geography students. In Florida, Adamski, Fraser and Peiro (2013) modified TOSRA to form the Test of Spanish Related Attitudes and used it with 223 grade 4-6 students learning Spanish.

\section{Field of learning environments}

One promising way to evaluate the 'effects and affects' of the integration of ICTs into school classrooms (Zandvliet 2003) involves the field of learning environments. For an instrument to evaluate the effectiveness of this new, technology-supported teaching and learning environment, the What Is Happening In this Class? (WIHIC, Aldridge, Fraser and Huang 1999) was a logical starting point for our study. However, an enhanced version of the WIHIC, the Technology-Rich Outcomes-Focused Learning Environment Inventory (TROFLEI, Aldridge and Fraser 2008), was the chosen instrument.

Historical perspectives

Research and evaluation in education have relied too heavily on academic achievement because these measures alone cannot give a complete view of students' educational processes which must include their perceptions of and reactions to their learning environment (Fraser 1998a, 1998b). Early work in field theory by Lewin (1936) focused on the idea that the 
environment and the interaction of the individual in that environment are significant contributors to human behaviour. A needs-press model was proposed by Murray (1938) as personality characteristics were studied in the context of achieving goals. This foundational work in business settings influenced the study of environments in educational settings.

In the field of education, the work by Herbert Walberg and Rudolf Moos in the USA formed the basis of modern learning environment research. As part of an evaluation of Harvard Project Physics (Walberg and Anderson 1968), the Learning Environment Inventory (LEI) was developed and became widely used. Student perceptions of the classroom environment were used with 2100 high school juniors and seniors in an evaluation of the Harvard Project Physics course, which included several instruments including the precursor to the LEI, namely, the Classroom Climate Questionnaire (Anderson and Walberg 1968). The study revealed a relationship between climate and learning, and that some climate variables were able to predict science learning or achievement in physics.

Concurrent with but independent from this work, Moos (1974) developed a scheme for categorising human environments. Relationship Dimensions address the extent to which people are personally involved in an environment as well as their support of one another. Personal Development Dimensions assess personal growth and development. System Maintenance and System Change Dimensions address the extent to which the environment involves order, expectations and responsiveness to change. Following extensive research in hospital, prison and university residence environments, the Classroom Environment Scale (CES) emerged (Moos 1974; Moos and Trickett 1974, 1987). It is from the foundations laid by Walberg and Moos that the study of classroom learning environments developed into a significant body of research (Aldridge and Fraser 2008; Fisher and Khine 2006; Fraser 1986, 2012, 2014). 
While much of past classroom environment research focused on science and computer-assisted classrooms, research in the Netherlands expanded the learning environment field by drawing on a communications processes theory (Watzlawick, Beavin and Jackson 1967) in which communication is a system in which the behaviours of the participants exert influence on each other. This theory was applied in the area of interpersonal relationships between teachers and students through the development of the Questionnaire on Teacher Interaction (QTI) (Wubbels, Créton and Hooymayers 1985). In the system of mapping teacher interpersonal behaviour, the behaviour of the teacher is impacted by the behaviour of the students, who are then impacted by the behaviour of the teacher. The validity of the QTI has been confirmed by studies in the Netherlands (Créton and Wubbels 1984; Wubbels and Brekelmans 2012; Wubbels, Creton and Hooymayers 1985), which revealed scale alpha reliability coefficients higher 0.70 at the student unit of analysis, and even higher with the class as the unit of analysis. When the QTI was also used to examine the relationships between QTI scales and student outcomes (Wubbels and Brekelmans 2012; Wubbels, Brekelmans and Hooymayer 1991), teacher behaviour scales such as Strict, Leadership and Helping/Friendly were linked to higher outcome scores, while the teacher behaviour scales of Student Responsibility/Freedom, Uncertain and Dissatisfied were found to impact outcome scores negatively.

The development of the field of learning environments has been facilitated in important ways by the birth of the American Educational Research Association's Special Interest Group (SIG) on Learning Environments in 1984, Springer's Learning Environments Research: An International Journal in 1998 and Sense Publishers' book series Advances in Learning Environment Research in 2008.

WIHIC and TROFLEI questionnaires 
The What Is Happening In this Class? (WIHIC) questionnaire is the most widely-used learning environment questionnaire around the world today (Aldridge and Fraser 2000; Chionh and Fraser 2009) and it formed the basis for the questionnaire used in my study (namely, the Technology-Rich Outcomes-Focused Learning Environment Inventory, TROFLEI) (Aldridge and Fraser 2008). The WIHIC incorporates scales which had demonstrated their value in predicting learning outcomes in earlier studies, as well as scales for measuring issues of growing social importance such as equity. The extensiveness of past research with the WIHIC is demonstrated in 22 studies reviewed by Fraser (2012) involving its use in six languages (English, Mandarin, Indonesian, Korean, Arabic and Spanish) in many countries (Australia, the USA, Canada, the UK, Taiwan, Indonesia, Singapore, India, Korea, South Africa and the UAE). Some recent studies involving the use of the WIHIC include Fraser, Aldridge and Adolphe (2010), Cohn and Fraser (in press), Oser and Fraser (2015) and Long and Fraser (2015).

The TROFLEI draws upon all seven of the WIHIC scales of Student Cohesiveness, Teacher Support, Involvement, Investigation, Task Orientation, Cooperation and Equity and it also includes the three additional scales of Differentiation, Computer Usage and Young Adult Ethos. The TROFLEI contains 80 items in 10 scales (Aldridge and Fraser 2008), with all items belonging to a particular scale being arranged in a single block rather than randomly.

Because the TROFLEI is a relatively-recent instrument, it has been validated and used in a limited number of past studies. Drawing upon data from 2317 Australian students in 166 classrooms, Aldridge and Fraser (2008) investigated the TROFLEI's factorial validity and internal consistency reliability. This study revealed strong factorial validity and internal consistency indices for the TROFLEI similar to those reported in previous studies that used the WIHIC (Fraser 2012; Fraser and Raaflaub 2013). Aldridge, Dorman and Fraser (2004) used multitrait-multimethod modeling with TROFLEI responses from a sample of 1249 
students, of whom 772 were from Western Australia and 477 were from Tasmania. When the 10 TROFLEI scales were used as traits and the actual and preferred forms of the instrument as methods, the results supported the TROFLEI's construct validity and sound psychometric properties, as well as indicating that the actual and preferred forms share a common structure.

The TROFLEI recently was translated, validated and used in Turkey with a sample of 980 grade 9-12 students, as well as English-language version being used with 130 grade 9-12 students in the USA (Welch, Cakir, Peterson and Ray 2012). For both actual preferred forms and for both Turkey and USA, the TROFLEI exhibited sound reliability and factorial validity when confirmatory factor analysis was used. In New Zealand, Koul, Fisher and Shaw (2011) used the TROFLEI with a sample of 1027 high-school students from 30 classes. As well as cross-validating the TROFLEI in both its actual and preferred forms, this study revealed sex and grade-level differences in perceptions, as well as associations between students' attitudes and their classroom environment perceptions.

Using learning environment criteria in evaluating educational initiatives

One of the past applications of classroom environment assessments that is directly relevant to our study is their use as criteria of effectiveness in the evaluation of educational innovations or new educational programs. The significance of these past evaluation studies is that classroom environment variables differentiated revealingly by between educational alternatives even when outcome measures showed small differences. Examples of these studies are summarised below:

- When Nix, Fraser and Ledbetter (2005) used the Constructivist Learning Environment Survey in their evaluation of an innovative teacher development program among 445 students in 25 classes in Texas, the students of teachers who had experienced this 
professional development program perceived their classrooms as having appreciably higher levels of Personal Relevance and Uncertainty relative to comparison classes.

- Lightburn and Fraser (2007) used the Science Laboratory Environment Inventory (SLEI) among 761 high-school biology students in Florida in an evaluation of the effectiveness of using anthropometric activities. Relative to a comparison group, the anthropometric group had higher scores on some learning environment and attitude scales.

- Aldridge and Fraser (2008) used the Technology-Rich Outcomes-Focused Learning Environment Inventory in evaluating the success of an innovative new school in Western Australia over four years. Analyses of data from over 1000 students revealed statistically significant changes of moderate magnitude (from 0.20 to 0.38 standard deviations) for seven of the 10 learning environment scales during the time period.

- In New York, Wolf and Fraser (2008) used the What Is Happening In this Class? (WIHIC) in their evaluation of the efficacy of using inquiry-based laboratory activities with middle-school science students. Inquiry instruction was found to promote more Student Cohesiveness than non-inquiry approaches and to be differentially effective for male and female students.

- In Singapore, Khoo and Fraser (2008) adapted the WIHIC for their evaluation of adult computer courses among a sample of 250 working adults. Generally students perceived their classroom environments positively, but males perceived significantly more Involvement whereas females perceived more Equity. 
- Martin-Dunlop and Fraser (2008) evaluated an innovative science course for preservice elementary teachers in a large urban university in California. Administration of selected WIHIC and SLEI scales to 525 females in 27 classes revealed very large differences of over 1.5 standard deviations on all scales between students' perceptions of the innovative course and previous courses.

\section{Method}

Questionnaire scales

Our evaluation of online resources, in terms of the learning environment and student attitudes to mathematics, involved tracing changes over a 10-week period on 13 questionnaire scales. As noted above, using learning environment assessments as criteria of effectiveness in evaluating educational programs has been a major focus in past learning environment research (Fraser 2012, 2014). Changes in the student-perceived learning environment were monitored with the 10 8-item TROFLEI scales of Student Cohesiveness, Teacher Support, Involvement, Young Adult Ethos, Investigation, Task Orientation, Cooperation, Equity, Differentiation and Computer Usage. We assessed students' attitudes to mathematics with the three 8-item scales of Enjoyment of Mathematics Lessons, Attitude to Mathematical Inquiry and Normality of Mathematicians. These three attitude scales were based on the Test of Mathematical Related Attitudes (TOMRA), that has been used previously by Spinner and Fraser (2005) and Ogbuehi and Fraser (2007) and which is based on the widely-used Test of Science Related Attitudes (TOSRA, Fraser 1981).

Table 1 clarifies the meaning of the 10 TROFLEI and 3 TOMRA scales by providing a scale description for each. The TROFLEI was an obvious choice of a classroom environment questionnaire because the online resource being evaluated had both an outcomes 
and a technology focus. Moreover, even though the central aim of the online resource was to prepare students for statewide achievement tests, still it was of paramount importance to ascertain whether using the resource had a positive, neutral or negative effect on the classroom learning environment and students attitudes to mathematics.

Sample

Our sample comprised 914 general-education students in 49 grade 6-8 mathematics classes in Miami, Florida. Data were collected on two separate occasions, first as a pretest, and later as a posttest after 10 weeks of implementation of the FCAT Explorer. The school district where our study was conducted is the fourth largest in the US, has a student enrolment of approximately 350,000, and an ethnic composition comprising a majority of Hispanic students (66.7\%), followed by $23.5 \%$ Black Non-Hispanic, $8 \%$ White Non-Hispanic and $1.8 \%$ Other (American-Indian, Asian, and Multiracial students). Spanish is the primary language for about half of the students and Haitian-Creole is the primary language for $5 \%$ of students.

The middle school at which our study was conducted was established in 1998 for grades 6 to 8 students. The enrolment at this school is 1165 students and its ethnic composition is: Hispanic $65.1 \%$, Black Non-Hispanic $12.8 \%$, White Non-Hispanic $17.9 \%$ and Other 4.3\%. Eight years ago, this school became the first in MDCPS to be authorised as an International Baccalaureate Middle Years Programme, which is offered school-wide at the three grade levels. The school is made up entirely of portable classrooms that were used as temporary housing during the reconstruction effort after Hurricane Andrew in 1992. 
Our study combined quantitative and qualitative methods as recommended by Fraser and Tobin (1991) and Tobin and Fraser (1998). Whereas quantitative data-collection methods involving questionnaires comprised our primary approach, a small but still important component of our approach involved qualitative data collection involving the use of interviews with a subsample of students. Our qualitative data gathering and analysis of themes were guided by Patton (2002), as well as the learning environment studies reported by Aldridge and Fraser (2008) and Aldridge, Fraser \& Huang (1999).

Qualitative data collection consisted of a series of questions posed in a personal interview format which provided reasons for student responses to the questionnaire. Students were invited to participate in the interviews on a voluntary basis and they were chosen based upon their achievement scores in their current class, with some students from the upper achievement quartile, some from the middle quartiles and some from the lowest quartile. A total of 24 students were interviewed over the course of three weeks after the online resource program was completed. Of the 24 students, 9 were male and 15 female. There were 3 students from the $7^{\text {th }}$ grade and 21 students from the $8^{\text {th }}$ grade. Interview questions were designed to probe the constructs encompassed by the TROFLEI and TOMRA: Teacher Support, Investigation and Task Orientation, Student Cohesiveness and Cooperation, Computer Usage, and Young Adult Ethos, with the final question allowing an open-ended response regarding the attitudes of Enjoyment of Lessons and Attitude to Inquiry.

Each interview followed the same format as closely as possible. After a few minutes of social conversation, we inquired about whether students were ready to answer a few questions about their mathematics class. The interview questions sought information about: what specific things their mathematics teacher did to help them to learn mathematics and how they solved mathematics problems; their opinion about the importance of working with other students when doing mathematics; their feelings towards using a computer when working on 
mathematics problems; some of the things that the student liked about mathematics class; and the main way in which using the FCAT Explorer program changed their attitudes about mathematics. The interviews lasted 7-12 minutes and interview notes were taken, as well as students being asked to record the highlights of their thoughts on a questionnaire.

\section{Results}

Validity and reliability of the questionnaires

In order to check the validity of the instruments, principal axis factor analysis with varimax rotation and Kaiser normalisation was conducted to investigate the structure and validity of the scales separately for the 10-scale TROFLEI and three-scale TOMRA. The criteria for the retention of any item were that it must have a factor loading of at least 0.40 with its own scale and less than 0.40 with all other scales. Items whose factor loadings did not meet these criteria were removed. As well, Cronbach's alpha coefficient was calculated for each scale as an index of its internal consistency reliability. Furthermore, an analysis of variance (ANOVA) was used to investigate each TROFLEI scale's capability of differentiating between students in different classes.

Responses from the sample of 914 students were factor analysed separately for pretest responses and posttest responses to the TROFLEI. Applying the criteria for the retention (that any item must have a factor loading of at least 0.40 on its own scale and less than 0.40 on each of the other nine TROFLEI scales) led to the identification and subsequent removal of 14 items, leaving the 66 items listed in Table 2. The items that were omitted were: Items 3, 5, 6 and 8 from Student Cohesiveness; Item 16 from Teacher Support; Items 19, 21, 22, 23 and 24 
from Involvement; Items 57, 58 and 61 from Differentiation; and Item 72 from Computer Usage.

Table 2 shows that, for the refined version of the TROFLEI containing 66 items in the original 10 scales, every item's factor loading was greater than 0.40 on its own scale and less than 0.40 on each of the other nine TROFLEI scales. The bottom of Table 2 indicates that the proportion of variance accounted for ranged from $2.18 \%$ to $7.36 \%$ for pretest responses to different TROFLEI scales, with the total variance accounted for by all 10 pretest scales being $50.94 \%$. For the posttest, the percentage of variance accounted for by different scales ranged from $1.39 \%$ to $8.03 \%$, with the total variance being $57.14 \%$. As shown in Table 2, eigenvalues for different TROFLEI scales ranged from 1.44 to 5.30 for the pretest and from 2.10 to 4.86 for the posttest.

Table 3 displays the internal consistency reliability using the Cronbach alpha coefficient for each TROFLEI scale for two units of analysis, the individual and the class mean, and separately for pretest and posttest responses. This table shows that the alpha reliability coefficient for the 10 different TROFLEI scales for the individual unit of analysis ranged from 0.76 to 0.97 for the pretest and from 0.83 to 0.93 for the posttest. With the class mean unit of analysis, alpha coefficients ranged from 0.83 to 0.97 for the pretest and from 0.90 to 0.97 on the posttest. These values indicate a high degree of internal consistency reliability.

The ability of the TROFLEI to differentiate between classes is an important characteristic for a classroom environment instrument (but is not relevant for the attitude questionnaire). While students within the same classroom should have similar perceptions of that classroom, students' perceptions should be different from classroom to classroom. Table 3 shows the ANOVA results for each TROFLEI scale for the posttest when class membership was used as the independent variable. The eta ${ }^{2}$ statistic, which is the ratio of the 'between' to 
'total' sum of the squares, represents the proportion of variance explained by class membership for each TROFLEI scale. Table 3 shows that every TROFLEI scale demonstrated significant differences $(p<0.01)$ between classrooms. Values of eta ${ }^{2}$ ranged from 0.08 for Student Cohesiveness to 0.25 for Teacher Support.

Overall the results support the TROFLEI's factorial validity, internal consistency reliability, and ability to discriminate between classrooms. These results with grade 6-8 mathematics students in Florida replicate the findings of the limited number of prior validations of the TROFLEI involving samples of 2137 Australian students (Aldridge and Fraser 2008), 1249 Australian students (Aldridge, Dorman and Fraser 2004; Dorman and Fraser 2009), 980 students in Turkey and 130 students in the USA (Welch, Cakir, Peterson and Ray 2012) and 1027 students in New Zealand (Koul, Fisher and Shaw 2011).

For the attitude scales of Enjoyment of Mathematics Lessons, Attitude to Mathematical Inquiry and Normality of Mathematicians drawn from the TOMRA and included in this study, a similar principal axis factoring with varimax rotation and Kaiser normalisation was carried out with the sample of 914 students in 49 classes. Factor analysis of the pretest and posttest responses was conducted separately. The same criteria for retention used for the TROFLEI, namely, a factor loading of at least 0.40 on its own scale and less than 0.40 on the other two TOMRA scales, were used. The Appendix displays the factor analysis results and confirms that all 24 TOMRA items satisfied the criteria for retention. The total proportion of variance accounted for was $58.22 \%$ for the pretest and $65.32 \%$ for the posttest.

The bottom row of the Appendix displays the internal consistency reliability using the Cronbach alpha coefficient for each TOMRA scale for two units of analysis and separately for pretest and posttest responses. This Appendix shows that, with the student as the unit of analysis, the alpha reliability coefficient for the three TOMRA scales ranged from 0.85 to 
0.95 for the pretest and from 0.90 to 0.95 for the posttest. These values indicate a high degree of internal consistency reliability for all TOMRA scales.

Evaluation of the online resource

For our second and main question, involving an evaluation of the FCAT Explorer in terms of classroom environment and student attitudes, differences between pretest and posttest scores for the 10 TROFLEI and three TOMRA scales were investigated using effect sizes and MANOVA with repeated measures. The interval between pretest and posttest was 10 weeks. For each TROFLEI scale, Table 4 shows the average item mean, average item standard deviation, and the difference between the pretest and posttest (effect size and ANOVA results). For the pretest environment scales, the average item mean ranged from 2.05 to 4.47, and it ranged from 2.14 to 4.43 for the posttest.

A MANOVA with repeated measures was conducted for the pretest-posttest changes in the set of 10 learning environment and 3 attitude scales. Because the multivariate test using Wilks' lamda criterion revealed statistically significant pre-post differences for the whole set of dependent variables, the results for the individual ANOVA with repeated measures was interpreted for each of the 13 scales. The ANOVA results in Table 4 show that pre-post differences were statistically significant for 8 of the 10 learning environment scales and none of the attitude scales. Over the time when FCAT Explorer was used, students perceived significantly more Involvement, Investigation, Differentiation and Computer Usage, but significantly less Teacher Support, Task Orientation, Cooperation and Equity.

Table 4 also provides the effect size for each scale to portray the magnitude of pre-post differences. The effect size, which is the difference between pretest and posttest means expressed in standard deviation units, is calculated by dividing the difference between 
means by the pooled standard deviation. The effect sizes for the pre-post differences for different scales in Table 4 range in magnitude from 0.00 to 0.19 standard deviations and are all classified as small according to Cohen's (1988) criteria. Moreover, changes between pretest and posttest represent an increase in scores for 6 scales, a decrease in scores for 6 scales, and a zero change for 1 scale.

Overall, in terms of pre-post changes for the learning environment and attitude scales used in our study, Table 4 suggests that the use of FCAT Explorer provided neither much advantage nor much disadvantage. Although the learning environment and attitudes seemed to improve a little on some TROFLEI scales, they also deteriorated a little on some other scales.

This analysis of pre-post differences provides insights into the specific areas in which students' perceptions of classroom environment changed slightly but significantly over the 10-week period during which the FCAT Explorer was used. Scales for which there was a significant increase in scores between pretest and posttest included items such as "Students discuss with me how to go about solving problems" (Involvement), "I carry out investigations to answer questions that puzzle me" (Investigation), "I work at my own speed" (Differentiation) and "I use the computer to type my assignments" (Computer Usage). Sample items from the scales for which there was a significant decrease in scores between pretest and posttest include "The teacher helps me when I have trouble with my work" (Teacher Support), "I know how much work I have to do" (Task Orientation), "I share my books and resources with other students when doing assignments" (Cooperation) and "I am treated the same as other students in this class" (Equity).

The finding that there was little advantage or disadvantage to using the online resource seems consistent with the 'no significant difference phenomenon' (Russell 1999) associated with many forms of technology-assisted instruction. Over the last century, research on 
numerous technological enhancements to education reviewed by Russell - including loudspeakers, phonographic recordings, instructional radio, television, electronic blackboard, e-reader/tablet devices, and other computer-assisted content delivery software programs - has revealed no significant differences.

Qualitative data collection and thematic analysis

Qualitative data based on interviews were employed to help to substantiate and embellish the findings based on quantitative questionnaire data. Combining the two techniques of quantitative and qualitative data collection has been advocated and used successfully in learning environments research (Aldridge, Fraser and Huang 1999; Fraser and Tobin 1991; Tobin and Fraser 1998). Although qualitative data collection played a less prominent role than did quantitative data collection, nonetheless, the qualitative component still was important.

As noted in the Methods section, our qualitative data collection consisted of 7-12 minute interviews with 24 students involved in the research. Table 5 provides for each scale the associated question posed to the students and sample responses.

The qualitative data collection drew upon six core questions that related to the scales from the TROFLEI, together with one of the questions allowing an open-ended response regarding attitudes towards mathematics that would potentially correspond to the attitude scales included in the modified TOMRA. Each response ranged from a single sentence to a paragraph, providing a data set of 144 responses with the word-for-word response being the unit of analysis. We analysed the responses for recurring themes and then provided a tabulation of the emerging themes in columnar format similar to that reported by Taylor and Fraser (2013). 
As well as giving a sense of the students' perceptions of their learning environment in their own words, students' responses seemed to fall into recurring themes that could be categorised. Using a scheme for coding data that leads to linking to an idea or topic that then leads to a theme (Richards and Morse 2007), an inductive process was used similar to a conceptual factor analysis. Our analysis of word-for-word interview response data involved a method documented by several researchers (Patton 2002; Silverman 2000; Taylor and Fraser 2013). This technique uses themes that develop from the interview responses and combines those themes into higher-order groupings of the main conceptual ideas of those themes. This forms an analysis structure with three levels. The first level is the student response, or the initial unit of analysis. The second level begins to combine responses into a higher-order grouping of the responses (Idea/Topic level). The Idea/Topic level can be compared with factor analysis of quantitative data, but involves examining concepts. From this second level could be identified themes that took on the expected form of the scales used in the TROFLEI. Figure 1 shows the linked analysis.

As students reflected on their tasks, their process of learning and their perceptions of what was happening, several common Idea/Topics emerged. The first Idea/Topic related to Engagement and included activities that students found interesting, such as "helpful hints and strategies" and "riddles, rhymes and jingles". The second Idea/Topic was related to the Mathematical Process in which students identify the way in which they approach mathematics, including "learn directly using trial and error" and "answering our own questions". The next Idea/Topic included responses in which the students identified that the problem-solving process is a more concrete, methodical way, such as "I read the problem and solve it going step-by-step" and "I use formulas to solve the problem". The next Idea/Topic was derived from responses that described how students felt about working together, 
including "it is important for me to work with others" and "I learn better when I work with others".

The next Idea/Topic addressed a central theme of this research project, namely, how students felt about using the computer (which we refer to as Work Flow). Apart from the educational content presented to the students, they also responded conceptually to the computer as the tool that they used when undertaking their mathematical work. Responses included "I don't like using the computer to do mathematics", "I prefer pen and paper" and “it's very confusing”. The last Idea/Topic combined responses in which students described their internal feelings of self in the context of doing mathematics (Self Worth), including "I like the feeling I get when I understand what is being taught" and "I like being graded on what we learn".

Taking these Idea/Topics to a higher conceptual level was the next step. One goal of the qualitative data collection was to determine the consistency of students' verbal responses with the quantitative data. The Idea/Topics were guided by the questions posed to the students, they fall rather conveniently into the scales of the TROFLEI, and therefore they still fit with the intent of this research project. In reviewing Fig. 1, an association can be made between the Idea/Topics and the Themes. The Themes correspond to the scales of the TROFLEI, with Engagement and Participation corresponding to Teacher Involvement, with Mathematical Process, Cognition, Problem Solving and Skill Application corresponding to Investigation and Task, and with Group Work and Collaboration fitting well with the theme of Student Cohesiveness and Cooperation. The Idea/Topics of Work Flow and Work Output correspond to the TROFLEI themes of Computer, whereas Self Worth, Satisfaction and Boredom correspond to Young Adult Ethos. It is noteworthy that the reaction of the students to using the computer in the context of doing mathematics was almost universally negative. 


\section{Summary and conclusion}

In this article, we reported a cross-validation of the TROFLEI (Technology-Rich OutcomesFocused Learning Environment Inventory) when used in outcomes-focused and technologysupported classrooms among 914 middle-school mathematics students. Previously, the TROFLEI had been validated in a relatively-small number of studies. After the removal of 14 items during factor analysis, factor loadings for every item the original 10 scales were greater than 0.40 on their own scale and less than 0.40 on each of the other nine TROFLEI scales. The total proportion of variance accounted for by the TROFLEI scales was $50.94 \%$ (pretest) and $57.14 \%$ (posttest). The alpha reliability coefficient for the 10 TROFLEI scales with the individual as the unit of analysis ranged from 0.76 to 0.97 for the pretest and from 0.83 to 0.93 for the pottest. Overall, the results supported the validity of the TROFLEI.

Our main research aim was to evaluate the effectiveness of an online resource in mathematics in terms of changes in students' attitudes towards mathematics and their perceptions of their classroom learning environments. When MANOVA was used to evaluate the effectiveness of using FCAT Explorer in terms of changes in scores on 10 learning environment and 3 attitude scales, statistically significant changes emerged for some TROFLEI scales but not for the attitude scales. However, for the scales for which pre-post changes were statistically significant, changes were in the positive direction for some scales and in the negative direction for others. Moreover, the magnitude of the pre-post changes was small for every TROFLEI and attitude scale according to Cohen's (1988) criteria. Apparently, the use of FCAT Explorer was neither advantageous nor disadvantageous for this group of students. This finding of a lack of effectiveness associated with the use of technology is consistent with considerable past research reviewed by Russell (1999). 
The collection of quantitative data based on learning environment and attitude scales was supplemented by some qualitative data gathering involving interviews with 24 students with questions about five learning environment constructs and enjoyment of mathematics. From an analysis of themes using 144 interview responses in verbatim form, we derived 13 emergent Ideas/Topics which then were linked to five TROFLEI scales. Generally, the qualitative data supported the quantitative findings.

While more research is still required into the effectiveness of online resources, this study adds to the growing body of literature that supports the use of learning environment instruments to monitor the effects and affects of information technology in the classroom. Because the online resource that was evaluated in our study does not support the latest version of Mathematics Florida Standards (MAFS), it is no longer used. Nevertheless, because other online resources have emerged and offer the hope for improving student outcomes, our study is still valuable because it suggests that technology alone might not sustain that hope. However, an important insight from our study is that using this online resource did not result in a deleterious effect overall in terms of either the classroom learning environment or students' attitudes to mathematics. Further research using learning environment instruments hopefully can provide insights into this important phenomenon. 


\section{References}

Adamski, A., Fraser, B.J., \& Peiro, M.M. (2013). Parental involvement in schooling, classroom environment and student outcomes. Learning Environments Research, 16, 315-328.

Aiken, L.R. (2002). Attitudes and related psychosocial constructs: Theories, assessment, and research. Thousand Oaks, CA: Sage Publications.

Aldridge, J.M., Dorman, J.P., \& Fraser, B.J. (2004). Use of multitrait-multimethod modelling to validate actual and preferred forms of the Technology-Rich Outcomes-Focused Learning Environment Inventory (TROFLEI). Australian Journal of Educational and Developmental Psychology, 4, 110-125.

Aldridge, J.M., \& Fraser, B.J. (2000). A cross-national study of classroom environments in Taiwan and Australia. Learning Environments Research, 3, 101-134.

Aldridge, J.M., \& Fraser, B.J. (2008). Outcomes-focused learning environments (Advances in Learning Environments Research series). Rotterdam: Sense Publishers.

Aldridge, J.M., Fraser, B.J., \& Huang, I.T.C. (1999). Investigating classroom environments in Taiwan and Australia with multiple research methods. Journal of Educational Research, 93, 48-62.

Aldridge, J.M., Laugksch, R.C., \& Fraser, B.J. (2006). School-level environment and outcomes-based education in South Africa. Learning Environments Research, 9, 123147.

Allport, G.W. (1935). Attitudes. In C. Murchison (Ed.), Handbook of social psychology (pp. 798-844). Worcester, MA: Clark University Press.

Anderson, G.J., \& Walberg, H.J. (1968). Classroom climate and group learning. International Journal of Educational Sciences, 2, 175-189.

Ball, D.L., \& Cohen, D.K. (1999). Instruction, capacity, and improvement (CPRE Research Report No. RR-43). Philadelphia, PA: University of Pennsylvania, Consortium for Policy Research in Education.

Bell, B., Jones A., \& Carr, M. (1995). The development of the recent national New Zealand science curriculum. Studies in Science Education, 26, 73-105.

Bolliger, D.U., \& Martindale, T. (2004). Key factors in determining student satisfaction in online courses. International Journal on E-Learning, 31(1), 61-67.

Botha, R.J. (2002). Outcomes-based education and educational reform in South Africa. International Journal of Leadership in Education, 5, 361-371.

Chionh, Y.H., \& Fraser, B.J. (2009). Classroom environment, achievement, attitudes and selfesteem in geography and mathematics in Singapore. International Research in Geographical and Environmental Education, 18, 29-44.

Cohen, J. (1988). Statistical power analysis for the behavioral sciences $\left(2^{\text {nd }}\right.$ ed.). New York: Academic Press.

Cohn, S.T., \& Fraser, B.J. (in press). Effectiveness of student response systems in terms of learning environment, attitudes and achievement. Learning Environments Research.

Dick, W., \& Carey, J.O. (1996). The systematic design of instruction (4 ${ }^{\text {th }}$ ed.) New York: Harper Collins.

Dorman, J.P., \& Fraser, B.J. (2009). Psychosocial environment and affective outcomes in technology-rich classrooms: Testing a causal model. Social Psychology of Education, 12, 77-99.

Eagly, A.H., \& Chaiken, S. (1993). The psychology of attitudes. Fort Worth, TX; Harcourt Brace Jovanovich.

Education Commission of the States. (1995). "Outcomes-based" education: An overview. Denver, CO: Author. 
Evans, K.M., \& King, J.A. (1994). Research on OBE: What we know and don't know. Educational Leadership, 51(6), 12-17.

Fahy, P.J. (2000). Achieving quality with online teaching technologies. Paper presented at Quality Learning 2000 Inaugural International Symposium, Calgary, AB. (ERIC document Reproduction Service No. ED445197)

Faris, R. (1998). From elitism to inclusive education: Development of outcomes-based learning and post-secondary credit accumulation and transfer systems in England and Wales. Victoria, BC: Centre for Curriculum, Transfer and Technology.

Fisher, D.L., \& Khine, M.S. (Eds.). (2006). Contemporary approaches to research on learning environments: Worldviews. Singapore: World Scientific.

Fletcher, G.H. (2010). Race to the top: No district left behind. T. H. E. Journal, 37(10), 1718.

Forlin, C., \& Forlin, P. (2002). Outcomes-focused education for inclusion. Queensland Journal of Education, 18, 62-81.

Fraser, B.J. (1981). Test of Science-Related Attitudes. Melbourne, Australia: The Australian Council for Educational Research.

Fraser, B.J. (1986). Classroom environment. London: Croom Helm.

Fraser, B.J. (1998a). Classroom environment instruments: Development, validity and applications. Learning Environments Research, 1, 7-33.

Fraser, B.J. (1998b). Science learning environments: Assessment, effects, and determinants. In B.J. Fraser \& K.G. Tobin (Eds.), International handbook of science education (pp. 527-564). Dordrecht, The Netherlands: Kluwer Academic Publishers.

Fraser, B.J. (2012). Classroom learning environments: Retrospect, context and prospect. In B. J. Fraser, K. G. Tobin, \& C. J. McRobbie (Eds.), Second international handbook of science education (pp. 1191-1239). New York: Springer.

Fraser, B.J. (2014). Classroom learning environments: Historical and contemporary perspectives. In N.G Lederman \& S. K. Abell (Eds.), Handbook of research on science education. Volume II (pp. 104-117). New York: Routledge.

Fraser, B.J. Aldridge, J.M., \& Adolphe, F.S.G. (2010). A cross-national study of secondary science classroom environments in Australia and Indonesia. Research in Science Education, 40, 551-571.

Fraser, B.J., \& Raaflaub, C. (2013). Subject and sex differences in the learning environment Perceptions and attitudes of Canadian mathematics and science students using laptop computers. Curriculum \& Teaching, 28 (1), 57-58.

Fraser, B.J., \& Tobin, K. (1991). Combining qualitative and quantitative methods in classroom environment research. In B. J. Fraser \& H. J. Walberg (Eds.), Educational environments: Evaluation, antecedents and consequences (pp. 271-292). London, Pergamon.

Hawkes, M., \& Dennis, T. (2003). Supporting and assessing online interactions in higher education. Educational Technology, 43(4), 52-56.

Kanner, J.H., Runyon, R.P., \& Desiderato, O. (1954). Television in army training: Evaluation of television in army basic training. Washington, DC: George Washington University.

Keller, J.M. (1987). Development and use of the ARCS model of instructional design. Journal of Instructional Development, 10(3), 2-10.

Khine, M.S. (1996). The interaction of cognitive styles with varying levels of feedback in multimedia presentation. International Journal of Instructional Media, 23, 229-237.

Khoo, H.S., \& Fraser, B.J. (2008). Using classroom psychosocial environment in the evaluation of adult computer application courses in Singapore. Technology, Pedagogy and Education, 17, 67-81. 
Kim, J.K., \& Sharp, J.M. (2000). Investigating and measuring preservice elementary mathematics teachers' decision about lesson planning after experiencing technologically-enhanced methods instruction. The Journal of Computers in Mathematics and Science Teaching, 19, 317-338.

Kind, P., Jones, K., \& Barmby, P. (2007). Developing attitudes towards science measures. International Journal of Science Education, 29, 871-893.

Klopfer, L.E. (1971). Evaluation of learning in science. In B.S. Bloom, J.T. Hastings, \& G.F. Madaus (Eds.). Handbook on summative and formative evaluation of student learning (pp. 559-641). New York: McGraw-Hill.

Koul, R.B., Fisher, D.L., \& Shaw, T. (2011). An application of the TROFLEI in secondaryschool science classes in New Zealand. Research in Science \& Technological Education, 29, 147-167.

Lewin, K. (1936). Principles of topological psychology. New York: McGraw Hill.

Lightburn, M.E., \& Fraser, B.J. (2007). Classroom environment and student outcomes among students using anthropometry activities in high school science. Research in Science \& Technological Education, 25, 153-166.

Long, C., \& Fraser, B.J. (2015). Comparison of alternative sequencing of middle-school science curriculum: Classroom learning environment and student attitudes. Curriculum and Teaching, 30(1), 23-36.

Martin-Dunlop, C., \& Fraser, B.J. (2008). Learning environment and attitudes associated with an innovative course designed for prospective elementary teachers. International Journal of Science and Mathematics Education, 6, 163-190.

McGuire, W.J. (1969). The nature of attitudes and attitude change. In G. Lindzey \& E. Aronson (Eds.), Handbook of social psychology ( $3^{\text {nd }}$ ed., Vol. 2, pp. 233-246). New York: Random House.

McKernan, J. (1993). Some limitations of outcomes-based education. Journal of Curriculum and Supervision, 8, 343-353.

Moos, R.H. (1974). The social climate scales: An overview. Palo Alto, CA: Consulting Psychologists Press.

Moos, R.H., \& Trickett, E.J. (1974). Classroom Environment Scale manual. Palo Alto, CA: Consulting Psychologists Press.

Moos, R.H., \& Trickett, E.J. (1987). Classroom Environment Scale manual (2nd ed.). Palo Alto, CA: Consulting Psychologists Press.

Munby, H. (1983). An investigation into the measurement of attitudes in science education. Columbus, OH: Ohio State University. ERIC Document \#ED 237347.

Munby, H. (1997). Issues of validity in science attitude measurement. Journal of Research in Science Teaching, 34, 337-341.

Naime-Diefenbach, B. (1991). Validation of attention and confidence as independent components of the ARCS motivational model. Unpublished doctoral dissertation. Florida State University, Tallahassee.

Nix, R., Fraser, B.J., \& Ledbetter, C. (2005). Evaluating an integrated science learning environment using the Constructivist Learning Environment Survey. Learning Environments Research, 8, 109-133.

Ogbuehi, P.I., \& Fraser B.J. (2007). Learning environment, attitudes and conceptual development associated with innovative strategies in middle-school mathematics. Learning Environments Research, 10, 101-114.

Osborne, J., Simons, S., \& Collins, S. (2003). Attitudes towards science: A review of the literature and its implication. International Journal of Science Education, 25, 10491079. 
Oser, R., \& Fraser, B.J. (2015). Effectiveness of virtual laboratories in terms of learning environment, attitudes and achievement among high-school genetics students. Curriculum and Teaching, 30(2), 65-80.

Patton, M. (2002). Qualitative research and evaluation methods (3rd ed.). Thousand Oaks, CA: Sage Publications.

Quek, C.L., Wong, A.F.L., \& Fraser, B. (2005). Teacher-student interaction and gifted students' attitudes toward chemistry in laboratory classrooms in Singapore. Journal of Classroom Interaction, 40(1), 18-28.

Richards, L., \& Morse, J.M. (2007). Users guide for qualitative methods $\left(2^{\text {nd }}\right.$ ed.). Thousand Oaks, CA: Sage.

Russell, T.L. (1999). The no significant difference phenomenon. Raleigh, NC: North Carolina State University.

Schibeci, R.A., \& McGaw, B. (1981). Empirical validation of the conceptual structure of a test of science-related attitudes. Educational and Psychological Measurement, 41, 1195-1201.

Schoenfeld, A. (1992). Learning to think mathematically: Problem solving, metacognition, and sense making in mathematics. In D.A. Grouws (Ed.), Handbook of research on mathematics teaching and learning (pp. 334-370). New York: Macmillan.

Silverman, D. (2000). Analyzing talk and text. In N.K. Denzin \& Y.S. Lincoln (Eds.), Handbook of qualitative research ( $2^{\text {nd }}$ ed.) (pp. 821-834). Thousand Oaks, CA: Sage Publications.

Spady, W. (1993). Outcomes-based education. Canberra: Australian Curriculum Studies Association.

Spady, W. (1994). Outcomes-based education: Critical issues and answers. Arlington, VA: American Association of School Administrators

Spinner, H., \& Fraser, B.J. (2005). Evaluation of an innovative mathematics program in terms of classroom environment, student attitudes, and conceptual development. International Journal of Science and Mathematics Education, 3, 267-293.

Taylor, B.A., \& Fraser, B.J. (2013). Relationships between learning environment and mathematics anxiety. Learning Environments Research, 16, 297-313.

Tobin, K., \& Fraser, B.J. (1998). Qualitative and quantitative landscapes of classroom learning environments. In B.J. Fraser \& K.G. Tobin (Eds.), International handbook of science education (pp. 623-640). Dordrecht, The Netherlands: Kluwer Academic Publishers.

Verzoni, K.A. (1997). Turning students into problem solvers. Mathematics Teaching in the Middle School, 3, 102-107.

Waghid, Y. (2003). Peters' non-instrumental justification of education view revisited: Contesting the philosophy of outcomes-based education in South Africa. Studies in Philosophy and Education, 22,245-265.

Walberg, H.J., \& Anderson, G.J. (1968). Classroom climate and individual learning. Journal of Educational Psychology, 59, 414-419.

Walker, S.L. (2006). Development and validation of the Test of Geography-Related Attitudes (ToGRA). Journal of Geography, 105, 175-181.

Watzlawick, P., Beavin, J., \& Jackson, D. (1967). The pragmatics of human communication. New York: Norton.

Welch, A.G., Cakir, M., Peterson, C., \& Ray, C.M. (2012). A cross-cultural validation of the Technology-Rich Outcomes-Focused Learning Environment Inventory (TROFLEI) in Turkey and the USA. Research in Science and Technological Education, 30, 49-63. 
Wolf, S.J., \& Fraser, B.J. (2008). Learning environment, attitudes and achievement among middle-school science students using inquiry-based laboratory activities. Research in Science Education, 38, 321-341.

Wong, A.F.L., Young, D.J., \& Fraser, B.J. (1997). A multilevel analysis of learning environments and student attitudes. Educational Psychology, 17, 449-468.

Wubbels, Th., Brekelmans, M., \& Hooymayers, H. (1991). Interpersonal teacher behaviour in the classroom. In B.J. Fraser, \& H.J. Walberg (Eds.), Educational environments: Evaluation, antecedents and consequences (pp. 141-160). Oxford, UK: Pergamon.

Wubbels, Th., \& Brekelmans, M. (2012). Teacher-students relationships in the classroom. In B.J. Fraser, K.G. Tobin \& C.J. McRobbie (Eds.), Second international handbook of science education (pp. 1241-1255). New York: Springer.

Wubbels, Th., Créton, H.A., \& Hooymayers, H.P. (1985, March-April). Discipline problems of beginning teachers: Interactional teacher behaviour mapped out. Paper presented at annual meeting of the American Education Research Association, Chicago.

Zandvliet, D. (2003, April). Learning environments in Malaysian "Smart School" classrooms. Paper presented at the annual meeting of the American Educational Research Association, Chicago. 


\section{Appendix}

Factor Analysis Results and alpha reliability for pretest and posttest for TOMRA

\begin{tabular}{|c|c|c|c|c|c|c|}
\hline \multirow{3}{*}{ Item } & \multicolumn{6}{|c|}{ Factor loadings } \\
\hline & \multicolumn{2}{|c|}{ Enjoyment } & \multicolumn{2}{|c|}{ Inquiry } & \multicolumn{2}{|c|}{ Normality } \\
\hline & Pre & Post & Pre & Post & Pre & Post \\
\hline 1 & 0.77 & 0.78 & & & & \\
\hline 2 & 0.71 & 0.73 & & & & \\
\hline 3 & 0.80 & 0.82 & & & & \\
\hline 4 & 0.85 & 0.86 & & & & \\
\hline 5 & 0.87 & 0.87 & & & & \\
\hline 6 & 0.85 & 0.84 & & & & \\
\hline 7 & 0.79 & 0.78 & & & & \\
\hline 8 & 0.73 & 0.76 & & & & \\
\hline 9 & & & 0.51 & 0.65 & & \\
\hline 10 & & & 0.58 & 0.68 & & \\
\hline 11 & & & 0.43 & 0.52 & & \\
\hline 12 & & & 0.65 & 0.73 & & \\
\hline 13 & & & 0.56 & 0.65 & & \\
\hline 14 & & & 0.66 & 0.72 & & \\
\hline 15 & & & 0.68 & 0.69 & & \\
\hline 16 & & & 0.68 & 0.71 & & \\
\hline 17 & & & & & 0.58 & 0.74 \\
\hline 18 & & & & & 0.65 & 0.80 \\
\hline 19 & & & & & 0.81 & 0.81 \\
\hline 20 & & & & & 0.79 & 0.85 \\
\hline 21 & & & & & 0.78 & 0.80 \\
\hline 22 & & & & & 0.76 & 0.81 \\
\hline 23 & & & & & 0.82 & 0.83 \\
\hline 24 & & & & & 0.66 & 0.72 \\
\hline$\%$ variance & 22.67 & 23.42 & 13.98 & 17.84 & 21.57 & 24.06 \\
\hline Eigenvalue & 5.44 & 5.62 & 3.35 & 4.28 & 5.18 & 5.77 \\
\hline ha reliability & 0.95 & 0.95 & 0.85 & 0.90 & 0.92 & 0.95 \\
\hline
\end{tabular}

Factor loadings smaller than 0.40 have been omitted.

The sample consisted of 914 students in 49 classes.

The total proportion of variance accounted for was $58.22 \%$ for the pretest and $65.32 \%$ for the posttest. 


\section{List of figures}

Fig. 1 Analysis of student responses by idea/topic and theme 


\section{Student Responses}

"He gives us helpful hints and strategies."

"He makes up riddles \& rhymes \& jingles to help us remember formulas; very interactive."

"He lets us solve our own problems so we can learn directly using trial and error procedure."

"He makes us answer the questions we ask. This makes us independent and helps us learn."

"I read the problem and go step by step using the appropriate formula."

"I solve the problems with certain formulas I have learned throughout the year."

"It is important for me to work with others. I learn better like that."

"It is a little important, that way if I do some-" thing wrong, I can learn from other people who know how, so I learn from my mistakes."

"I honestly do not like using the computer to do math. I prefer everything on paper."

'I don't like doing math on the computer. I can't write out my work on the computer screen. It is very confusing."

"I like working with new people and the feeling I get when I understand what is being taught."

"The feeling I get when I understand the problem. When I get and answer right, I feel more knowledgeable and successful."

"The problems are fun and puzzle-like. The teacher doesn't bore the class, and we get graded on what we learned rather than what a test grade says."

\section{Idea/Topic}

Engagement

Participation

Mathematical

Process

Cognition

Problem Solving

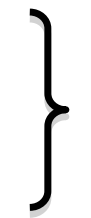

Skill Application

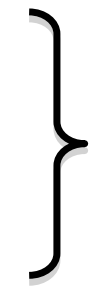

Group Work

Collaboration

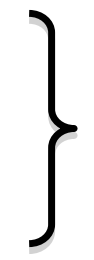

Work Flow

Work Output



Self Worth

Satisfaction

Boredom

\section{Theme}

Teacher

Involvement

Investigation and Task

Student

Cohesiveness

and

Cooperation

Computer
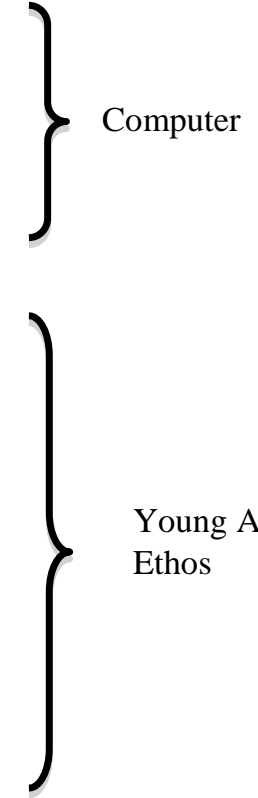

Young Adult

Ethos

Fig. 1 
Table 1 Scale description for each TROFLEI and TOMRA scale

Scale Description

The extent to which ...

Technology-Rich Outcomes-Focused Learning Environment Inventory (TROFLEI)

Student Cohesiveness

Teacher Support

Involvement

Investigation

Task Orientation

Cooperation

Equity

Differentiation

Computer Usage

Young Adult Ethos

Test of Mathematics Related Attitudes (TOMRA)

Enjoyment of Mathematics Lessons

Attitude to Mathematical Inquiry

Normality of Mathematicians
Students know, help and are supportive of one another. The teacher helps, befriends, trusts and is interested in students.

Students have attentive interest, participate in discussions, do additional work and enjoy the class.

Emphasis is placed on the skills and processes of inquiry and their use in problem solving and investigation.

It is important to complete activities planned and to stay on the subject matter.

Students cooperate rather than compete with one another on learning skills

Students are treated equally by the teacher

Teachers cater for students differently on the basis of ability, rates of learning and interests.

Students use computers as a tool to communicate with others and to access information.

Teachers give students responsibility and treat them as young adults.

Students enjoy and look forward to mathematics lessons

Students value inquiry as a method for learning mathematics

Students view mathematics as normal (rather than as the eccentrics sometimes displayed in the media) 
Table 2 Factor analysis results for the TROFLEI for pretest and posttest

\begin{tabular}{|c|c|c|c|c|c|c|c|c|c|c|c|c|c|c|c|c|c|c|c|c|}
\hline \multirow{3}{*}{$\begin{array}{l}\text { Item } \\
\text { no. }\end{array}$} & \multicolumn{20}{|c|}{ Factor loadings } \\
\hline & \multicolumn{2}{|c|}{$\begin{array}{c}\text { Student } \\
\text { Cohesiveness }\end{array}$} & $\begin{array}{l}\text { Teac } \\
\text { Supp }\end{array}$ & & Involv & ement & Inves & tigatio & $\begin{array}{r}T_{\mathrm{T}} \\
\text { Orien }\end{array}$ & $\begin{array}{l}\text { isk } \\
\text { tation }\end{array}$ & Coop & ration & Equ & & & $\begin{array}{l}\text { eren- } \\
\text { tion }\end{array}$ & & $\begin{array}{l}\text { puter } \\
\text { gige }\end{array}$ & $\begin{array}{r}\text { Yo } \\
\text { Adult }\end{array}$ & $\begin{array}{l}\text { ung } \\
\text { Ethos }\end{array}$ \\
\hline & Pre & Post & Pre & Post & $\overline{P r e}$ & Post & $\overline{\operatorname{Pre}}$ & Post & Pre & Post & Pre & Post & Pre & Post & Pre & Post & Pre & Post & Pre & Post \\
\hline 1 & 0.68 & 0.79 & & & & & & & & & & & & & & & & & & \\
\hline 2 & 0.56 & 0.62 & & & & & & & & & & & & & & & & & & \\
\hline 4 & 0.77 & 0.79 & & & & & & & & & & & & & & & & & & \\
\hline 7 & 0.64 & 0.63 & & & & & & & & & & & & & & & & & & \\
\hline 9 & & & 0.60 & 0.64 & & & & & & & & & & & & & & & & \\
\hline 10 & & & 0.66 & 0.67 & & & & & & & & & & & & & & & & \\
\hline 11 & & & 0.68 & 0.67 & & & & & & & & & & & & & & & & \\
\hline 12 & & & 0.50 & 0.47 & & & & & & & & & & & & & & & & \\
\hline 13 & & & 0.63 & 0.69 & & & & & & & & & & & & & & & & \\
\hline 14 & & & 0.68 & 0.74 & & & & & & & & & & & & & & & & \\
\hline 15 & & & 0.63 & 0.67 & & & & & & & & & & & & & & & & \\
\hline 17 & & & & & 0.57 & 0.61 & & & & & & & & & & & & & & \\
\hline 18 & & & & & 0.73 & 0.68 & & & & & & & & & & & & & & \\
\hline 20 & & & & & 0.53 & 0.50 & & & & & & & & & & & & & & \\
\hline 25 & & & & & & & 0.61 & 0.71 & & & & & & & & & & & & \\
\hline 26 & & & & & & & 0.56 & 0.59 & & & & & & & & & & & & \\
\hline 27 & & & & & & & 0.70 & 0.72 & & & & & & & & & & & & \\
\hline 28 & & & & & & & 0.56 & 0.62 & & & & & & & & & & & & \\
\hline 29 & & & & & & & 0.74 & 0.76 & & & & & & & & & & & & \\
\hline 30 & & & & & & & 0.80 & 0.78 & & & & & & & & & & & & \\
\hline 31 & & & & & & & 0.74 & 0.74 & & & & & & & & & & & & \\
\hline 32 & & & & & & & 0.69 & 0.70 & & & & & & & & & & & & \\
\hline 33 & & & & & & & & & 0.63 & 0.67 & & & & & & & & & & \\
\hline 34 & & & & & & & & & 0.61 & 0.62 & & & & & & & & & & \\
\hline 35 & & & & & & & & & 0.60 & 0.65 & & & & & & & & & & \\
\hline 36 & & & & & & & & & 0.59 & 0.64 & & & & & & & & & & \\
\hline 37 & & & & & & & & & 0.66 & 0.67 & & & & & & & & & & \\
\hline 38 & & & & & & & & & 0.62 & 0.59 & & & & & & & & & & \\
\hline 39 & & & & & & & & & 0.60 & 0.67 & & & & & & & & & & \\
\hline 40 & & & & & & & & & 0.57 & 0.64 & & & & & & & & & & \\
\hline 41 & & & & & & & & & & & 0.57 & 0.55 & & & & & & & & \\
\hline 42 & & & & & & & & & & & 0.55 & 0.58 & & & & & & & & \\
\hline 43 & & & & & & & & & & & 0.54 & 0.49 & & & & & & & & \\
\hline 44 & & & & & & & & & & & 0.52 & 0.47 & & & & & & & & \\
\hline 45 & & & & & & & & & & & 0.59 & 0.62 & & & & & & & & \\
\hline 46 & & & & & & & & & & & 0.65 & 0.68 & & & & & & & & \\
\hline 47 & & & & & & & & & & & 0.63 & 0.63 & & & & & & & & \\
\hline 48 & & & & & & & & & & & 0.59 & 0.59 & & & & & & & & \\
\hline 49 & & & & & & & & & & & & & 0.56 & 0.58 & & & & & & \\
\hline 50 & & & & & & & & & & & & & 0.62 & 0.61 & & & & & & \\
\hline 51 & & & & & & & & & & & & & 0.71 & 0.69 & & & & & & \\
\hline 52 & & & & & & & & & & & & & 0.74 & 0.74 & & & & & & \\
\hline 53 & & & & & & & & & & & & & 0.73 & 0.77 & & & & & & \\
\hline 54 & & & & & & & & & & & & & 0.72 & 0.76 & & & & & & \\
\hline 55 & & & & & & & & & & & & & 0.61 & 0.68 & & & & & & \\
\hline 56 & & & & & & & & & & & & & 0.69 & 0.67 & & & & & & \\
\hline 59 & & & & & & & & & & & & & & & 0.46 & 0.51 & & & & \\
\hline 60 & & & & & & & & & & & & & & & 0.58 & 0.65 & & & & \\
\hline 62 & & & & & & & & & & & & & & & 0.70 & 0.75 & & & & \\
\hline 63 & & & & & & & & & & & & & & & 0.57 & 0.63 & & & & \\
\hline 64 & & & & & & & & & & & & & & & 0.59 & 0.63 & & & & \\
\hline 65 & & & & & & & & & & & & & & & & & 0.53 & 0.58 & & \\
\hline 66 & & & & & & & & & & & & & & & & & 0.64 & 0.73 & & \\
\hline 67 & & & & & & & & & & & & & & & & & 0.66 & 0.74 & & \\
\hline 68 & & & & & & & & & & & & & & & & & 0.73 & 0.74 & & \\
\hline 69 & & & & & & & & & & & & & & & & & 0.78 & 0.81 & & \\
\hline 70 & & & & & & & & & & & & & & & & & 0.76 & 0.82 & & \\
\hline 71 & & & & & & & & & & & & & & & & & 0.44 & 0.57 & & \\
\hline 73 & & & & & & & & & & & & & & & & & & & 0.58 & 0.61 \\
\hline 74 & & & & & & & & & & & & & & & & & & & 0.54 & 0.55 \\
\hline 75 & & & & & & & & & & & & & & & & & & & 0.50 & 0.49 \\
\hline 76 & & & & & & & & & & & & & & & & & & & 0.56 & 0.60 \\
\hline 77 & & & & & & & & & & & & & & & & & & & 0.64 & 0.60 \\
\hline 78 & & & & & & & & & & & & & & & & & & & 0.62 & 0.60 \\
\hline 79 & & & & & & & & & & & & & & & & & & & 0.62 & 0.66 \\
\hline 80 & & & & & & & & & & & & & & & & & & & 0.48 & 0.54 \\
\hline iance & 3.46 & 3.85 & 5.71 & 6.24 & 2.23 & 2.04 & 7.12 & 8.05 & 6.00 & 7.54 & 5.60 & 5.61 & 7.38 & 8.19 & 3.02 & 3.63 & 5.34 & 6.47 & 5.35 & 5.55 \\
\hline nvalue & 2.28 & 2.54 & 3.77 & 4.12 & 1.47 & 1.34 & 4.70 & 5.31 & 3.96 & 4.98 & 3.70 & 3.70 & 4.87 & 5.40 & 1.99 & 2.40 & 3.53 & 4.27 & 3.53 & 3.66 \\
\hline
\end{tabular}

Items $3,5,6,8,16,19,21,22,23,24,57,58,61$ and 72 were omitted.

The sample consisted of 914 students in 49 classes.

Factor loadings smaller than 0.40 have been omitted.

The total proportion of variance accounted for was $50.94 \%$ for the pretest and $57.14 \%$ for the posttest. 
Table 3 Internal consistency reliability (Cronbach alpha coefficient) for two units of analysis and ability to differentiate between classrooms (ANOVA results) for pretest and posttest for TROFLEI

\begin{tabular}{|c|c|c|c|c|c|}
\hline \multirow[t]{2}{*}{ Scale } & \multirow[t]{2}{*}{ Unit of analysis } & \multirow{2}{*}{$\begin{array}{l}\text { No of } \\
\text { items }\end{array}$} & \multicolumn{2}{|c|}{ Alpha reliability } & \multirow{2}{*}{$\begin{array}{c}\text { ANOVA } \\
\text { Eta }^{2} \\
\text { Actual }\end{array}$} \\
\hline & & & Pre & Post & \\
\hline Student Cohesiveness & $\begin{array}{l}\text { Individual } \\
\text { Class mean }\end{array}$ & 4 & $\begin{array}{l}0.80 \\
0.84\end{array}$ & $\begin{array}{l}0.86 \\
0.90\end{array}$ & $0.08 * *$ \\
\hline Teacher Support & $\begin{array}{l}\text { Individual } \\
\text { Class mean }\end{array}$ & 7 & $\begin{array}{l}0.90 \\
0.97\end{array}$ & $\begin{array}{l}0.90 \\
0.97\end{array}$ & $0.25 * *$ \\
\hline Involvement & $\begin{array}{l}\text { Individual } \\
\text { Class mean }\end{array}$ & 3 & $\begin{array}{l}0.81 \\
0.91\end{array}$ & $\begin{array}{l}0.84 \\
0.94\end{array}$ & $0.15 * *$ \\
\hline Investigation & $\begin{array}{l}\text { Individual } \\
\text { Class mean }\end{array}$ & 8 & $\begin{array}{l}0.91 \\
0.96\end{array}$ & $\begin{array}{l}0.92 \\
0.96\end{array}$ & $0.11 * *$ \\
\hline Task Orientation & $\begin{array}{l}\text { Individual } \\
\text { Class mean }\end{array}$ & 8 & $\begin{array}{l}0.86 \\
0.90\end{array}$ & $\begin{array}{l}0.90 \\
0.94\end{array}$ & $0.12 * *$ \\
\hline Cooperation & $\begin{array}{l}\text { Individual } \\
\text { Class mean }\end{array}$ & 8 & $\begin{array}{l}0.87 \\
0.94\end{array}$ & $\begin{array}{l}0.87 \\
0.91\end{array}$ & $0.14 * *$ \\
\hline Equity & $\begin{array}{l}\text { Individual } \\
\text { Class mean }\end{array}$ & 8 & $\begin{array}{l}0.91 \\
0.97\end{array}$ & $\begin{array}{l}0.93 \\
0.97\end{array}$ & $0.16^{* *}$ \\
\hline Differentiation & $\begin{array}{l}\text { Individual } \\
\text { Class mean }\end{array}$ & 5 & $\begin{array}{l}0.76 \\
0.83\end{array}$ & $\begin{array}{l}0.83 \\
0.91\end{array}$ & $0.11 * *$ \\
\hline Computer Usage & $\begin{array}{l}\text { Individual } \\
\text { Class mean }\end{array}$ & 7 & $\begin{array}{l}0.84 \\
0.87\end{array}$ & $\begin{array}{l}0.89 \\
0.95\end{array}$ & $0.18 * *$ \\
\hline Young Adult Ethos & $\begin{array}{l}\text { Individual } \\
\text { Class mean }\end{array}$ & 8 & $\begin{array}{l}0.86 \\
0.94\end{array}$ & $\begin{array}{l}0.90 \\
0.96\end{array}$ & $0.17 * *$ \\
\hline
\end{tabular}

The sample consisted of 914 students in 49 classes.

The eta ${ }^{2}$ statistic (which is the ratio of 'between' to 'total' sums of squares) represents the proportion of variance explained by class membership. 
Table 4 Average item mean, average item standard deviation and difference between pretest and posttest (effect size and ANOVA results) for classroom environment and student attitude scales

\begin{tabular}{|c|c|c|c|c|c|c|}
\hline \multirow[t]{2}{*}{ Scale } & \multicolumn{2}{|c|}{ Average item mean } & \multicolumn{2}{|c|}{$\begin{array}{c}\text { Average item } \\
\text { standard deviation }\end{array}$} & \multicolumn{2}{|c|}{ Difference } \\
\hline & Pre & Post & Pre & Post & $\begin{array}{l}\text { Effect } \\
\text { size }\end{array}$ & $F$ \\
\hline \multicolumn{7}{|l|}{ Learning Environment } \\
\hline Student Cohesiveness & 4.42 & 4.43 & 0.62 & 0.69 & 0.02 & 0.47 \\
\hline Teacher Support & 3.56 & 3.49 & 0.97 & 0.98 & -0.07 & $7.06^{* *}$ \\
\hline Involvement & 2.93 & 3.05 & 1.07 & 1.09 & 0.11 & $11.22 * *$ \\
\hline Investigation & 3.28 & 3.35 & 0.94 & 0.97 & 0.07 & $5.06 *$ \\
\hline Task Orientation & 4.47 & 4.41 & 0.59 & 0.68 & -0.09 & $8.55^{* *}$ \\
\hline Cooperation & 3.87 & 3.81 & 0.81 & 0.83 & -0.07 & $4.93 *$ \\
\hline Equity & 4.33 & 4.23 & 0.82 & 0.90 & -0.12 & $16.32 * *$ \\
\hline Differentiation & 2.34 & 2.41 & 0.95 & 1.06 & 0.07 & $6.55^{*}$ \\
\hline Computer Usage & 2.05 & 2.14 & 0.94 & 1.07 & 0.09 & $6.55^{*}$ \\
\hline Young Adult Ethos & 4.19 & 4.19 & 0.80 & 0.80 & 0.00 & 0.00 \\
\hline \multicolumn{7}{|l|}{ Attitudes } \\
\hline Enjoyment & 2.94 & 3.02 & 0.50 & 0.52 & 0.16 & 3.04 \\
\hline Inquiry & 2.77 & 2.70 & 0.32 & 0.42 & -0.19 & 1.36 \\
\hline Normality & 2.63 & 2.56 & 0.43 & 0.49 & -0.15 & 1.46 \\
\hline
\end{tabular}

$* p<0.05, * * p<0.01$

The sample consisted of 914 students in 49 classes 
Table 5 Sample responses to interview questions

\begin{tabular}{|c|c|c|}
\hline Scale & Question & Sample responses \\
\hline Teacher Support & $\begin{array}{l}\text { Describe things that your } \\
\text { mathematics teacher does to } \\
\text { help you to learn mathematics. }\end{array}$ & $\begin{array}{l}\text { "My mathematics teacher uses } \\
\text { the FCAT Explorer program to } \\
\text { help me learn." }\end{array}$ \\
\hline Investigation and Task & Describe how you solve & "I look at the problem and I \\
\hline Orientation & mathematics problems. & $\begin{array}{l}\text { think what the problem is } \\
\text { asking for and what procedures } \\
\text { I have to take to solve the } \\
\text { problem. Then I solve the } \\
\text { problem." }\end{array}$ \\
\hline $\begin{array}{l}\text { Student Cohesiveness and } \\
\text { Cooperation }\end{array}$ & $\begin{array}{l}\text { How important is it to you to } \\
\text { work with other students when } \\
\text { you do mathematics? }\end{array}$ & $\begin{array}{l}\text { "It depends. Generally I'll talk } \\
\text { more but sometimes I } \\
\text { understand better when a } \\
\text { student explains something." }\end{array}$ \\
\hline Computer Usage & $\begin{array}{l}\text { Describe how you feel about } \\
\text { using the computer to work on } \\
\text { mathematics problems. }\end{array}$ & $\begin{array}{l}\text { "I don't really like it. I prefer } \\
\text { using pencil and paper." }\end{array}$ \\
\hline Young Adult Ethos & $\begin{array}{l}\text { Describe some things that you } \\
\text { like about mathematics class. }\end{array}$ & $\begin{array}{l}\text { "In my mathematics class, I like } \\
\text { the positive environment and I } \\
\text { enjoy having a teacher to } \\
\text { explain the problems and } \\
\text { answer my questions." }\end{array}$ \\
\hline Open-Ended Attitude item & $\begin{array}{l}\text { Describe the main way in which } \\
\text { FCAT Explorer has changed } \\
\text { your attitude about } \\
\text { mathematics. }\end{array}$ & $\begin{array}{l}\text { "FCAT Explorer has changed } \\
\text { my attitude about mathematics } \\
\text { by reminding me that there is } \\
\text { always more than one way to } \\
\text { solve problems." }\end{array}$ \\
\hline
\end{tabular}

